Proc. Estonian Acad. Sci. Geol., 1998, 47, 2, 108-129

\title{
DEVELOPMENT OF PEDOGENESIS ON AQUEOUS DEPOSITS WITHIN THE HOLOCENE IN WEST ESTONIA
}

\author{
Loit REINTAM ${ }^{\mathrm{a}}$ and Tanel MOORA ${ }^{\mathrm{b}}$
}

${ }^{a}$ Institute of Soil Science and Agrochemistry, Estonian Agricultural University, Eerika, EE-2400 b Tartu, Estonia

Institute of History, Rüütli 6, EE-0001 Tallinn, Estonia

Received 5 January 1998, in revised form 19 January 1998

\begin{abstract}
Holocene outcrops with multisequal soil sections on sediments of the Baltic transgressions were investigated on the site of the ancient settlement at Pulli and at Paikuse, West Estonia. Pedogenesis began on silty sand and sandy loam deposits after the rapid retreat of the Baltic Ice Lake about 10400 BP. The first Mesolithic settlement in Estonia was established at Pulli about $9600 \mathrm{BP}$, but the bones of herbivores amongst the archaeological findings indicate the presence of herbaceous vegetation and progress of the humus-accumulative process already at the Yoldia Stage. Within the Pre-Boreal, Mollic Gleysols with cambic properties were derived from Arenosols, whereas the annual rate of humus accumulation was $1.1-2.3 \mathrm{~g} \mathrm{~m}^{-2}$ per $1 \mathrm{~cm}$ of the epipedon enriched with phosphorus and iron in the area of the settlement. The $\mathrm{C}: \mathrm{N}$ and humic : fulvic ratios are 11-16 and 1.1-1.7, respectively. After the Ancylus transgression (95009000 BP) the Gleysols were buried by sands. The complex of Fluvisol properties formed shows that a decrease in the intensity of pedogenesis took place under the alluvial regime. Because of high permeability, and the mineral and chemical poverty of Ancylus sands, a Carbi-Gleyic Podzol developed then within less than 500 years. A rise of the groundwater table and an intensification of reductomorphic processes resulted in the degradation and transformation of both albic and spodic horizons. As a result of the step-by-step transgression and intermittent sedimentation of sands, in the Early Litorina Stage a short section of Mollic Gleysol was formed above Podzol during the following 800 years. Two sections of Arenosols are the uppermost within the multisequal outcrop profile. The humus, textural, and chemical status of all Gleysol, Fluvisol, Podzol, and Arenosol sections as well as their genesis in space and time are discussed.
\end{abstract}

Key words: Holocene pedogenesis, soil palaeosequences, archaeology in soil science. 


\section{INTRODUCTION}

In the course of time soil has been interpreted as a mirror objectively reflecting the development of natural processes in any ecological situation and expressing the complex of interactions between organic matter and mineral stratum; solar radiation, moisture, and gases; organisms and inanimate environment (Zonn, 1986; Buol et al., 1989). Individual soil sections, formed and differentiated on unlike parent materials, serve as the main source for establishing the nature of soil genesis and evolution. During the geological development of the territory, especially as a result of transgressions, older pedogenetic formations may have been buried under younger sediments on which soil formation commenced from the beginning. Such multisequal soil sections overlying each other are unique and rare because transgression processes usually break down relatively thin soil formations. Soils of different age in different transgression areas are better preserved in individual monogenetic profiles, although temporal and spatial changes might have taken place in their evolution (Reintam, 1995, 1997).

Multisequal soil sections (besides Podzols, probably also Arenosols) have been studied in Greenland (Jakobsen, 1991, 1992) where mostly coarse-textured tills and glaciofluvial sediments are covered by a mantle of Late-Glacial fine sands and coarse silt. A buried, but undisturbed arctic Podzol on fine sandy loam, underlain by coarse gravelly sand and covered by a very thin Arenosol, was described in Disko Island (Humlum et al., 1995). The first data on the occurrence of buried organogenic material at a depth of some $1.8 \mathrm{~m}$ in West Estonia were published in the late 1920s (Thomson, 1928, 1930). As a result of pollen analysis, spruce was found and the frequency of oak and hazel was described there. Further archaeological (some Stone Age findings) and stratigraphical investigations confirmed the presence of organogenic layers of different stages of the Holocene (Indreko, 1948; Kessel, 1963; Kessel \& Punning, 1969). These authors mentioned, described, and analysed peat and humous sands, but nobody attempted to discuss about the genetic nature and/or soil origin of these formations. It is even impossible to understand the formation of peat described: did it result either from paludification of dry land or from the overgrowth of water bodies. Nevertheless, trends and rates of pedogenesis, and the evolution of soils within the Holocene are of great importance not only for understanding the nature of contemporary objects and phenomena, but also for the characterization of the historic development of terrestrial ecosystems in time and space (Mahaney et al., 1980; Morozova, 1981; Aleksandrovski, 1983; Keeley, 1990). At that, archaeological information is of great value to any pedogenetic interpretation.

To provide coherent information on the pedogenetic activities in the Holocene, this paper aims to deal with the changes in the humus relationship and soil textural and chemical properties during the last ten millennia on multisequal sediments of the Baltic transgressions. 


\section{MATERIAL AND METHODS}

\section{Site description and sampling}

Two Holocene outcrops with multisequal soil sections on sediments of the Baltic transgressions were investigated in West Estonia (Fig. 1).

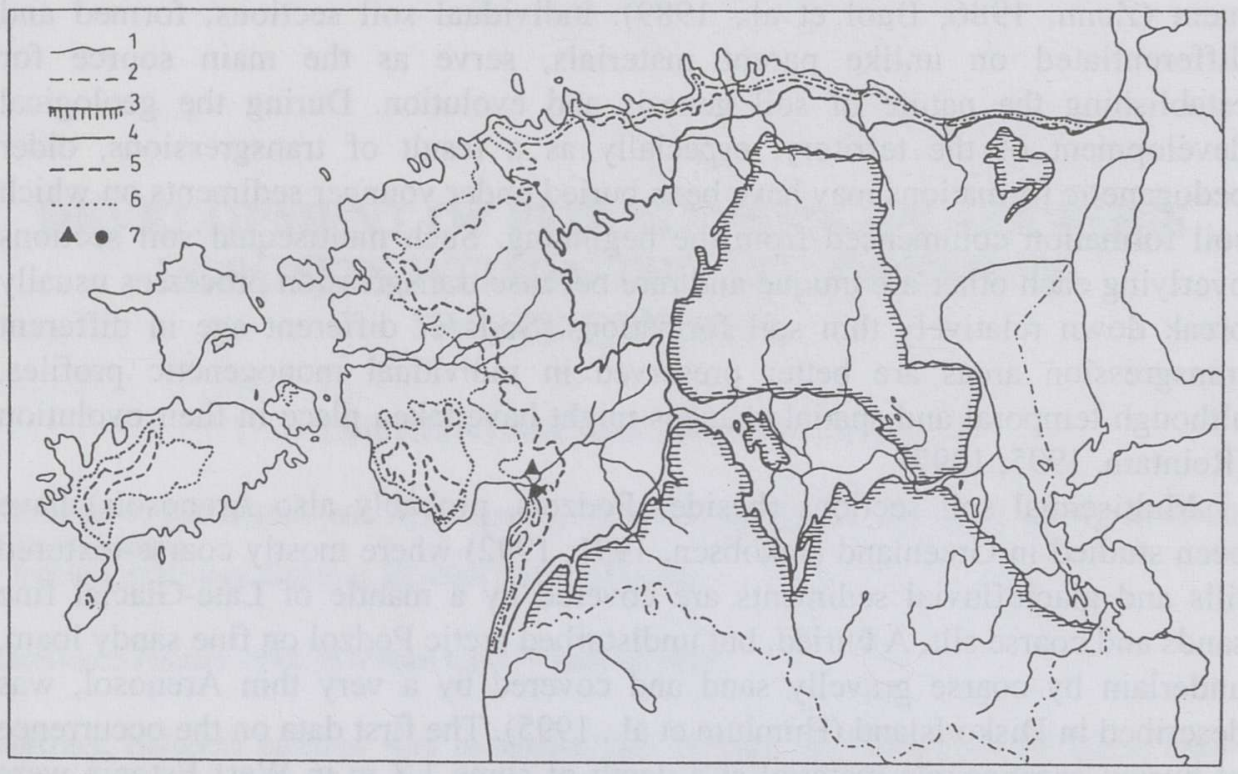

Fig. 1. Maximum lines of Baltic transgressions (compiled after A. Tammekann, K. Orviku, and $\mathrm{H}$. Kessel) and location of study sites. 1, modern shoreline and inland rivers; 2, boundary of the Republic of Estonia; 3, local ice lakes (boundary between Upper and Lower Estonia); 4, Baltic Ice Lake; 5, Ancylus Lake; 6, Litorina Sea; 7, study sites (A Pulli, Paikuse).

The Paikuse outcrop (Fig. 2, Photo 1) is located on the left bank of the Pärnu River (58 $22^{\prime} 45^{\prime \prime}$ N, $24^{\circ} 36^{\prime} 10^{\prime \prime}$ E) close to Paikuse Police School (former Sindi Manor House). The soil and sediment sequence of this outcrop, established in 1995, was as follows:

0-60 Cambic Arenosol on fine sand of (alluvio-) eolian origin.

60-86 Finely stratified silty sand with fluvic soil properties.

86-100 Gleyic Arenosol on alluvial or temporally transgressive Litorina silty sand.

100-165 Stratified Eutric Fluvisol on alluvial or transgressive/regressive Litorina silt and sand.

165-179 Dystri-Mollic Gleysol on sandy silt with diatoms in the coastal area of the temporally transgressive Litorina Sea.

179-204 Dwarf Carbi-Gleyic Podzol with pieces of charcoal on fine Ancylus sand. 


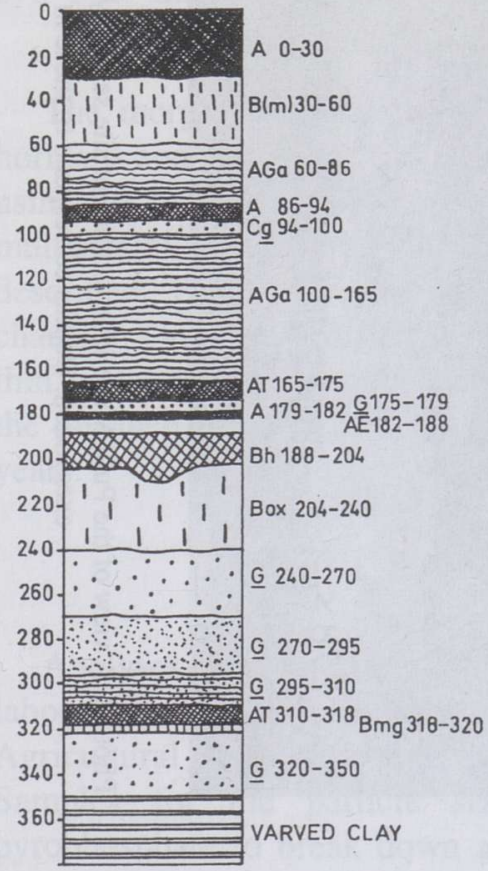

Fig. 2. Outcrop with multisequal soil sections at Paikuse.

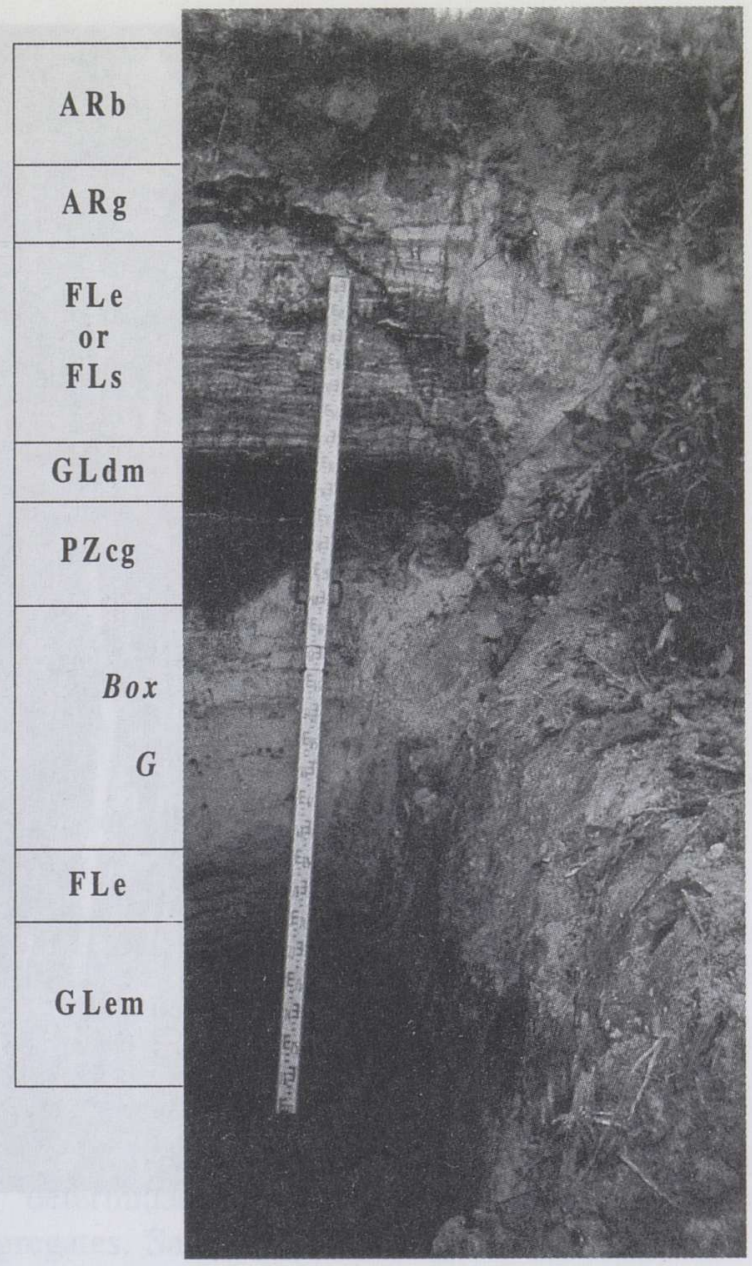

Photo 1. Outcrop with multisequal soil sections at Paikuse in 1997. Soils see Table 1. Additional to those: FLe, Eutric Fluvisol; FLs, Salic Fluvisol.

204-240 Fine Ancylus sand with sporadic rusty mottlings resulting from a seasonal reoxidation of sedimentary ferrous compounds.

240-310 Trisequal tixotropic fine Ancylus sands with different textural and chemical status in layers.

310-350 Eutri-Mollic Gleysol on silty sand of surface-bed and/or lakeside origin, deposited after and/or during the retreat of the Baltic Ice Lake.

$>350$ Varved clay.

The Pulli outcrop (Fig. 3, Photo 2) lies on the right bank of the Pärnu River, several hundred metres upstream from the old railway bridge $\left(58^{\circ} 25^{\prime} 10^{\prime \prime} \mathrm{N}\right.$, 

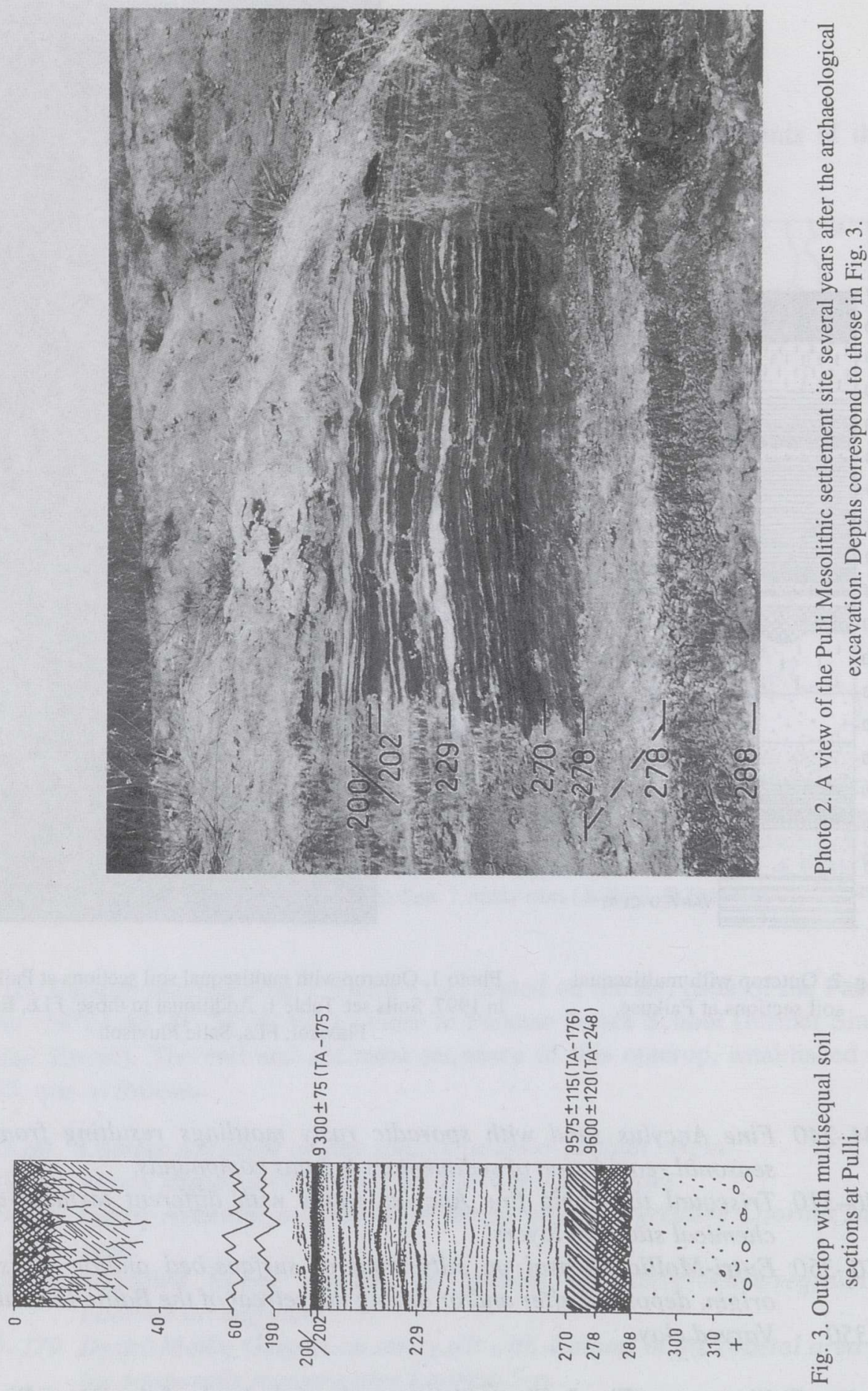
$24^{\circ} 40^{\prime} 30^{\prime \prime}$ E), on the well-known Mesolithic settlement site described by Jaanits et al. (1982). The following soils and sediments were recorded in this outcrop:

0-60 Cambic Arenosol or Cambic Podzol on pericoastal sand described before the sampling; destroyed by modern human activity.

60-190 Medium and coarse sand with gravel interlayers of coastal origin.

190-278 Eutri-Mollic Fluvisol on transgressive/regressive Ancylus silt, sand, and loam.

278-350 Eutri-Mollic Gleysol on sandy silt and loam of surface-bed and/or Preboreal lakeside origin.

The morphological description and soil sampling by different-aged genetic horizons and their parent materials were carried out in 1995 to a depth of $380 \mathrm{~cm}$ using the methods well known in soil science (Soil Survey, 1996). In 1997 the multisequal section at Paikuse was opened once again and morphologically described. Principally, the sequence of different-aged soil sections had not changed. Only some insignificant differences in the depth and/or appearance of thin horizons were observed because of their natural variability in the limits of the distance of up to $2-3 \mathrm{~m}$ off the river bank which had dropped during two years.

\section{Analyses}

Analyses were performed by the research assistant Raja Kährik in the laboratories of the Institute of Soil Science and Agrochemistry, Estonian Agricultural University. Fine earth less than $1 \mathrm{~mm}$ in particle size was used. Samples for the particle size determination were treated with sodium pyrophosphate to break down aggregates. Sands were sieved and the fractions finer than $0.05 \mathrm{~mm}$ were determined by pipette analysis. Total chemical analysis after the alkaline fusion treatment was carried out. Iron and aluminium were ascertained by means of sulphosalicylic acid and aluminone, respectively, alkaline earths, potassium, and sodium by the method of flame photometry. Carbonates were determined acidometrically to recalculate the measured data. The results obtained were expressed for the ignited noncalcareous material (Arinushkina, 1970). The authenticity of these techniques was verified by the method of atomic absorption spectrometry (AAS).

The group and fractional composition of humus was determined by the alternate acid-alkaline treatment using the Tyurin-Ponomareva volumetric method (Ponomareva, 1957). The results obtained were expressed in the percentage of organic carbon. The total percentages of organic carbon and nitrogen were ascertained by the Tyurin and Kjeldahl methods, respectively. Nonsiliceous iron was determined after Coffin, amorphous sesquioxides and silica after Tamm, and iron activity after Schwertmann (Zonn, 1982). ${ }^{14} \mathrm{C}$ data from Ilves et al. (1974) 
and Raukas \& Hyvärinen (1992) were used. Holocene stratigraphy was fixed after Raukas et al. (1995). FAO (Food and Agricultural Organization) terminology was used in the identification of soils (FAO, 1994).

\section{RESULTS AND DISCUSSION}

Retreat of the Fennoscandian ice-sheet some 12000 BP (Huckriede et al., 1996) opened the territory investigated for the organic-mineral interactions and pedogenesis on glacial sediments. The pedogenetic processes and spatial soil sequences developed on tills have been fairly well characterized (Lillema, 1958; Reintam, 1975, 1995). Up to now nobody has found ancient soil sections on tills below the varved sediments accumulated within the large freshwater Baltic Ice Lake. Eutric, Mollic, and Dystric Gleysols on varved clays have been described, analytically characterized, and drawn on soil maps of different scale in the area of the transgression of the Baltic Ice Lake (Paas, 1964, 1979, 1985; Rooma \& Reintam, 1976; Reintam, 1975; Rooma, 1996). One of us (Tanel Moora) has reported local remains of these soils on the top of varved clays even under the stratum of younger sediments, but they are lacking at Paikuse and Pulli (Figs. 2 and 3, Photos 1 and 2). Although in Scandinavia, approximately $10400 \mathrm{BP}$, the retreating ice margin opened a new connection to the North Sea via the Skagerrak at Mount Billingen in Sweden, and marine water invaded the Baltic Ice Lake (Huckriede et al., 1996), it seems plausible that the plain of varved clays in the surroundings of Pulli-Paikuse became dry land. Only shallow relict lakes were formed in the glaciolacustrine plains, which resulted in the local transformation and resedimentation of the uppermost varved sediments. A thin layer $(20-40 \mathrm{~cm})$ of silty sand and/or sandy loam above varved clay (Figs. 2 and 3 , Table 1) is aqueous in origin and accumulated in the surface-beds and/or regressive lakeside. Pollen is absent there, but at Paikuse this material contains seeds of club-rush (Schoenoplectus lacustris (L.) Palla), bog bean (Menyanthes trifoliata L.), and freshwater kinds of pondweed (Potamogeton spp.). The absence of seeds in the upper part of sand, transformed into soil, tends to demonstrate the partial terrigenic nature of the material.

Initial pedogenesis on these silty sand and sandy loam deposits became possible at the Yoldia Stage after the rapid retreat of the Baltic Ice Lake about 10400 BP. The first settlement of Mesolithic fishers and hunters was established at Pulli in favourable for life dry conditions about $9600 \mathrm{BP}$, whereas the bones of wild boar, roebuck, and red-deer amongst the archaeological findings indicate the presence of herbaceous vegetation and development of the humus-accumulative process at the Yoldia Period. These animals, in addition to the bones of relatively thermophilic bream and pike-perch found, indicate warming of the climate for this time as they could not survive hard winters. The fishes mentioned cannot spawn in cold water. The absence of the bones of perch and pike which are found 
on most other Mesolithic settlement sites suggests that the aquic soil regime prevailed there at least in early spring when these fishes spawn. Such a situation implies only seasonal human activity at the end of settlement existence.

Although initial heterogeneity of sediment layers underlain by varved clay could be possible, the pedogenetic weathering of sandy fractions, accumulation of silty and clayey ones, and development of cambic properties were obvious in the sections of Yoldia-age Gleysols (Table 1). These phenomena are impossible or weak in aquic conditions. That is why argillization in situ had taken place prior to intensive gleyization. Soil formation had started in automorphic conditions, which favoured also the population of the area by man. Within the

Table 1

Granulometric $(\varnothing \mathrm{mm})$ composition $(\%)$ of soils and sediments

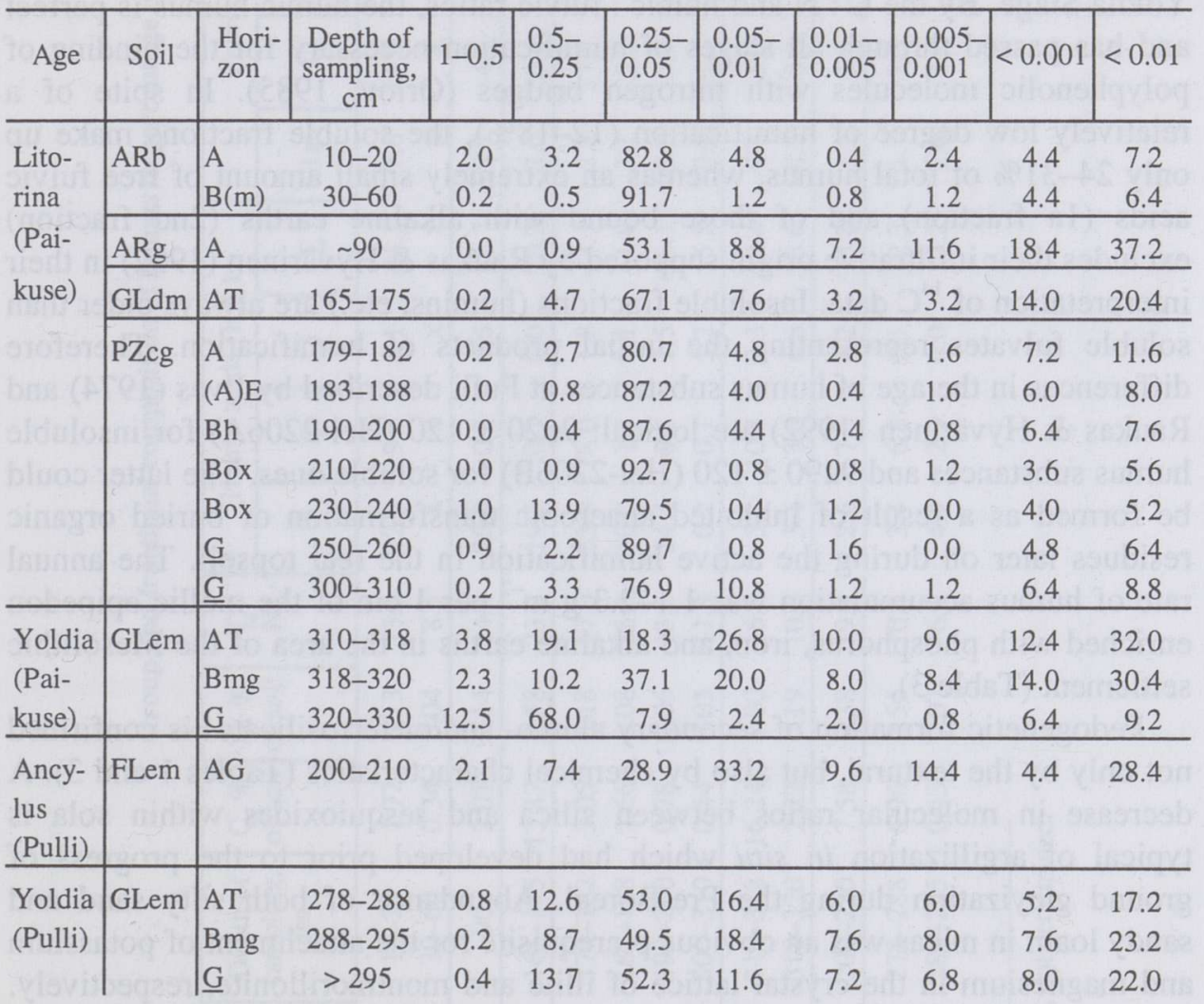

ARb, Cambic Arenosol; ARg, Gleyic Arenosol; GLdm, Dystri-Mollic Gleysol; GLem, Eutri-Mollic Gleysol; FLem, Eutri-Mollic Fluvisol; PZcg, Carbi-Gleyic Podzol. 
Pre-Boreal, the evolution of Arenosols and/or Cambisols through their gleyic formations into Gleysols took place as a result of an increase in hydromorphism. Without doubt this process was accompanied by the step-by-step abandonment of the Pulli settlement which became unsuitable for life due to the increasing paludification of the area.

During about 700-1200 years a Gleysol profile with earlier developed cambic properties was formed. Mineral constituents make up more than $70 \%$ of the AThorizon which represents the transformation product of the initial (probably ochric) A-horizon in the progress of aquic conditions. Histic and fimic properties, but not horizons can be sporadically found there. The organic carbon content is more than twice less in the mollic epipedon influenced by human activity at Pulli (Table 2) where the textural differentiation of profile is also weaker (Table 1). This seems to be a direct result of the intensification of mineralization phenomena which is up to now always accompanied by human impact on any Gleysol. However, qualitative properties of humus are quite similar in both sections of the Yoldia Stage. By the $\mathrm{C}: \mathrm{N}$ and humic : fulvic ratios, the humic humus is perfect and has passed through all stages of humification necessary for the binding of polyphenolic molecules with nitrogen bridges (Orlov, 1985). In spite of a relatively low degree of humification (12-18\%), the soluble fractions make up only $24-31 \%$ of total humus, whereas an extremely small amount of free fulvic acids (1a fraction) and of those bound with alkaline earths (2nd fraction) excludes their infiltrative origin supposed by Raukas \& Hyvärinen (1992) in their interpretation of ${ }^{14} \mathrm{C}$ data. Insoluble fractions (humins, etc.) are always older than soluble fulvates representing the initial products of humification. Therefore differences in the age of humus substances at Pulli described by Ilves (1974) and Raukas \& Hyvärinen (1992) are logical: $9620 \pm 120$ (Hel-2206A) for insoluble humus substances and $9290 \pm 120$ (Hel-2206B) for soluble ones. The latter could be formed as a result of inhibited anaerobic transformation of buried organic residues later on during the active humification in the real topsoil. The annual rate of humus accumulation was $1.1-2.3 \mathrm{~g} \mathrm{~m}^{-2}$ per $1 \mathrm{~cm}$ of the mollic epipedon enriched with phosphorus, iron, and alkaline earths in the area of the Mesolithic settlement (Table 3).

Pedogenetic formation of secondary alumo- and/or ferrosilicates is confirmed not only by the textural, but also by chemical characteristics (Tables 1 and 3). A decrease in molecular ratios between silica and sesquioxides within sola is typical of argillization in situ which had developed prior to the progress of ground gleyization during the Pre-Boreal. Abundance of both silty sand and sandy loam in micas was an obvious prerequisite for the attachment of potassium and magnesium in the crystal lattice of illite and montmorillonite, respectively. $\mathrm{Mg}$-vermiculite could also be derived directly from the biotite, but under reductomorphic conditions, likewise as a result of the vermiculitization and montmorillonitization of $\mathrm{Fe}-\mathrm{Mg}$-illite through the mixed-layered formations (Gorbunov, 1978). After Gorbunov (1978), the insertion of potassium, mobilized 


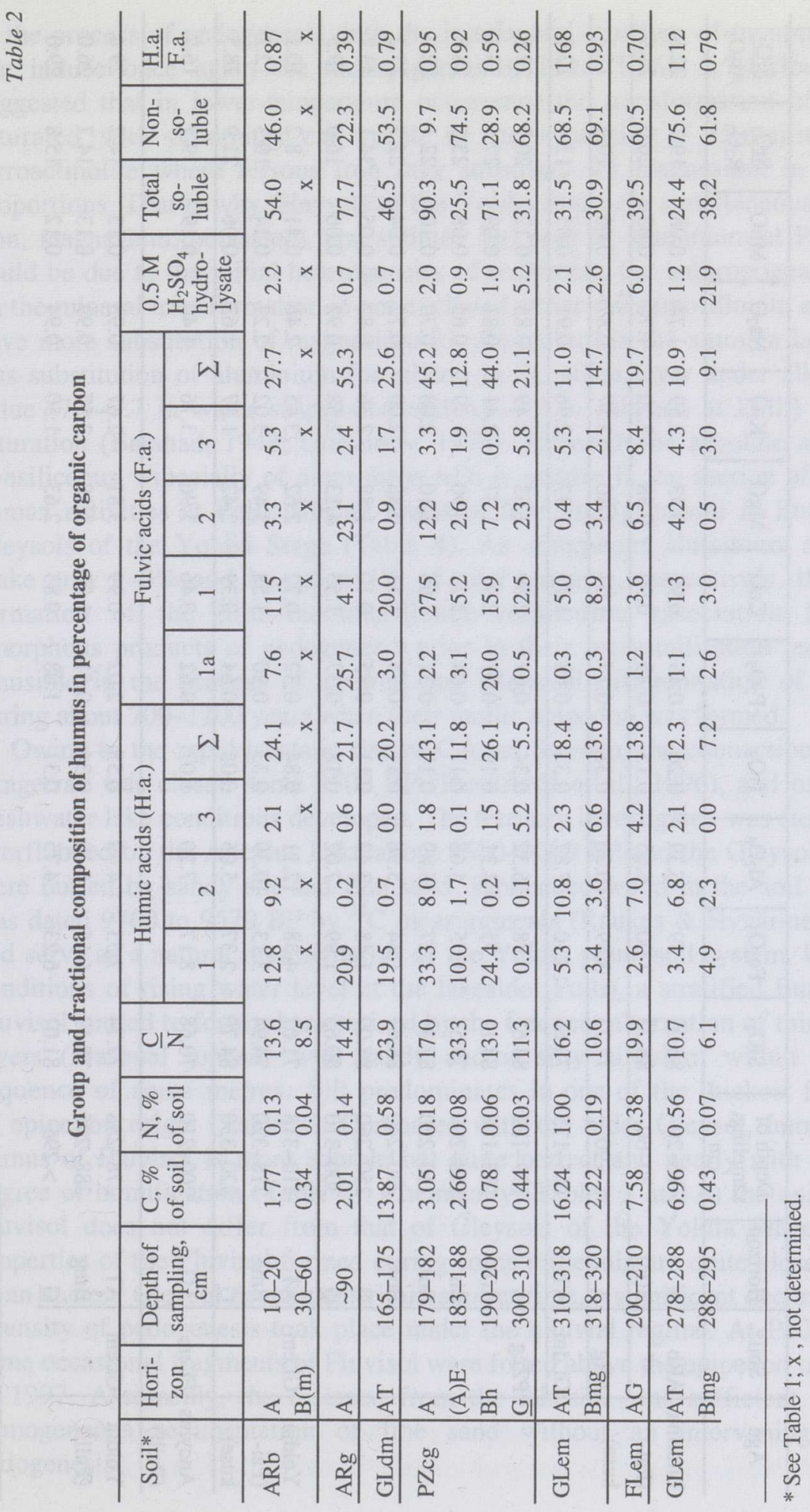


औั้

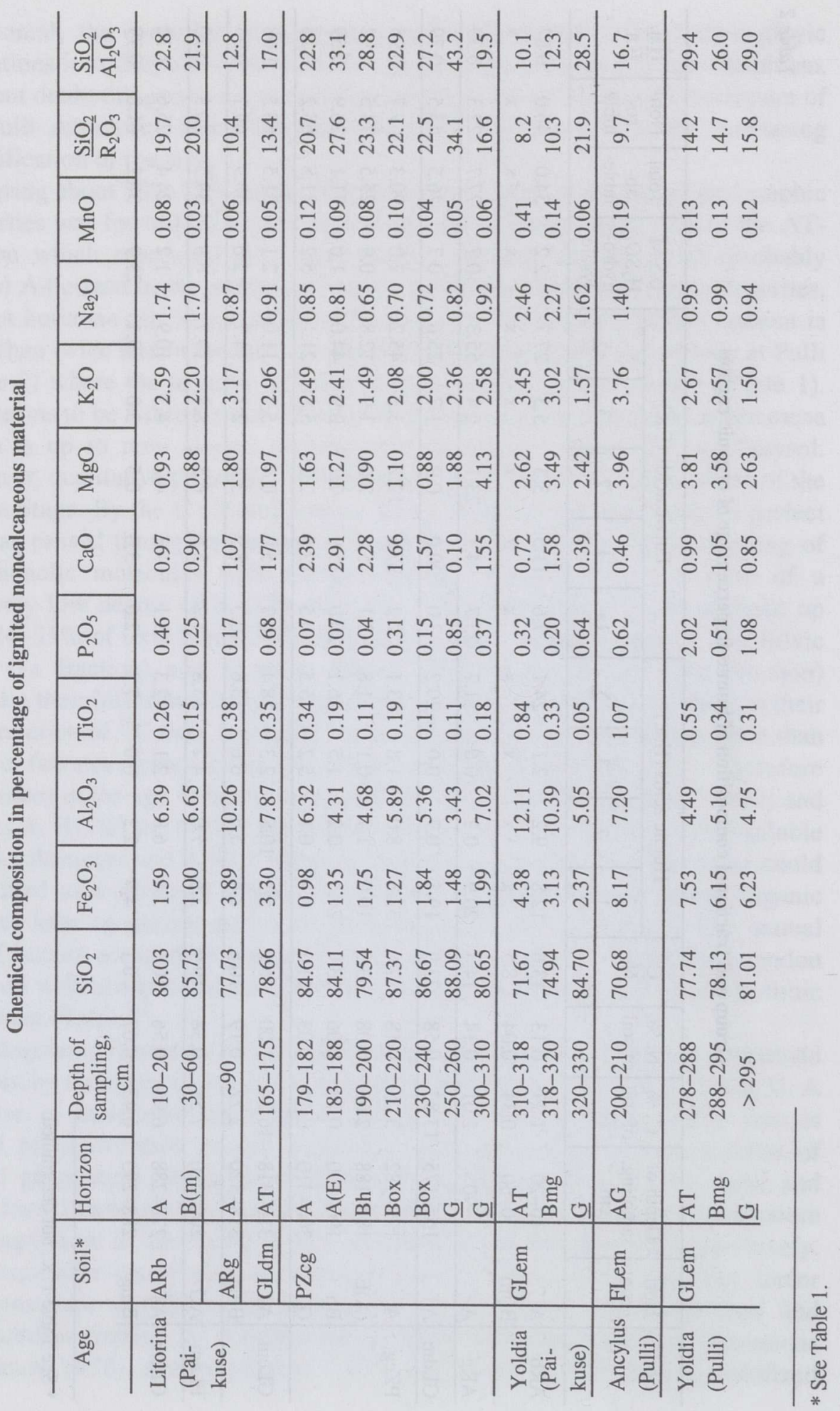


in the process of pedogenesis, into the interlayeral structure of montmorillonite can induce once again the reconjugation of illite. Klein \& Hurlbut (1993) suggested that in lower-temperature occurrence the transformation of silicates saturated with dolomites can result in the synthesis of ferrosilite and/or ferroactinolite where ferrous iron may substitute for magnesium in different proportions. That is why Gleysols of the Yoldia Stage are simultaneously rich in iron, magnesium, potassium, and sodium, but poor in aluminium at Pulli. This could be due to the initial heterogeneity of sediments, but anthropogenic impact on the mineral transformation is not excluded either. Montmorillonite appears to have more substitution of magnesium for aluminium in the alumina layers, and less substitution of aluminium for silicon in the silica layer under alkaline $\mathrm{pH}$ value (7.4-7.7 in water suspension and 6.8-7.0 in salt one at Pulli) and base saturation (Barshad, 1948; Gorbunov, 1978). Although the absolute amount of nonsiliceous, especially of amorphous iron is greater in the section affected by human activities at Pulli, silicate forms of iron highly prevail in Eutri-Mollic Gleysols of the Yoldia Stage (Table 4). As amorphous aluminium and silica make only $1-3 \%$ and less than $1 \%$ of total amounts, respectively, the partial formation of the illite-montmorillonite-vermiculite association from the amorphous products of pedogenesis prior to their recrystallization tends to be plausible in the process of textural and chemical differentiation of Gleysols during about 700-1200 years when their mollic epipedon was formed.

Owing to the rapid isostatic rise of Central Sweden, the connection with the Skagerrak was closed some 9500 BP (Huckriede et al., 1996), and once again freshwater lake conditions developed. The territory investigated was step-by-step overflooded by the Ancylus Lake about 9500-9000 BP and the Gleysols formed were buried by sandy silt and fine sand. Embedded wood in the soil epipedon was dated 9760 to $9570 \mathrm{BP}$ by ${ }^{14} \mathrm{C}$ measurements (Raukas \& Hyvärinen, 1992), and serve as a natural representative of the Yoldia plant-soil system. Under the conditions of rising water level at the lakeside (Pulli), a stratified Eutri-Mollic Fluvisol started to form, characterized by the frequent alternation of thin humous layers (seasonal topsoil) with sandy and/or silty alluvium within the total sequence of some metres. Silt predominates in one of the thickest formation of epipedon origin (Table 1). Compared with the older Gleysol, humic-fulvic humus of Fluvisol is more soluble but quite perfect and nearly with the same degree of humification (Table 2). Chemically (Tables 3 and 4) the epipedon of Fluvisol does not differ from that of Gleysols of the Yoldia Stage. As the properties of the Fluvisol formed during some millennia are quite close to those of an ancient Gleysol developed within shorter time, a significant decrease in the intensity of pedogenesis took place under the alluvial regime. At Paikuse only some occasional fragments of Fluvisol were found above the epipedon of Gleysol in 1997. Assumedly, the distance from the lakeside was sufficient there for homogeneous sedimentation of fine sand without an intervening alluvial pedogenesis. 
Nonsiliceous compounds (\%) of soil

\begin{tabular}{|c|c|c|c|c|c|c|c|c|c|c|c|}
\hline \multirow[t]{2}{*}{ Age } & \multirow[t]{2}{*}{ Soil* } & \multirow[t]{2}{*}{$\begin{array}{c}\text { Hori- } \\
\text { zon }\end{array}$} & \multirow{2}{*}{$\begin{array}{c}\text { Depth of } \\
\text { sampling, } \\
\mathrm{cm}\end{array}$} & \multirow{2}{*}{$\begin{array}{c}\text { Total } \\
\text { nonsi- } \\
\text { liceous } \\
\mathrm{Fe}_{2} \mathrm{O}_{3}\end{array}$} & \multicolumn{3}{|c|}{ Amorphous } & \multirow{2}{*}{$\begin{array}{c}\text { Fe- } \\
\text { activity, } \\
\%\end{array}$} & \multicolumn{3}{|c|}{$\begin{array}{c}\text { Composition of total } \\
\mathrm{Fe}_{2} \mathrm{O}_{3}, \%\end{array}$} \\
\hline & & & & & $\mathrm{Fe}_{2} \mathrm{O}_{3}$ & $\mathrm{Al}_{2} \mathrm{O}_{3}$ & $\mathrm{SiO}_{2}$ & & $\begin{array}{l}\text { Amor- } \\
\text { phous }\end{array}$ & \begin{tabular}{|c|} 
Crys- \\
talline
\end{tabular} & $\begin{array}{l}\text { Sili- } \\
\text { cate }\end{array}$ \\
\hline \multirow{11}{*}{$\begin{array}{l}\text { Lito- } \\
\text { rina } \\
\text { (Pai- } \\
\text { kuse) }\end{array}$} & $\mathrm{ARb}$ & & $10-20$ & 0.57 & 0.22 & 0.23 & 0.17 & 39 & 14 & 22 & 64 \\
\hline & & $\mathrm{B}(\mathrm{m})$ & $30-60$ & 0.47 & 0.18 & 0.20 & 0.01 & 38 & 22 & 25 & 53 \\
\hline & $\mathrm{ARg}$ & A & $\sim 90$ & 1.77 & 1.67 & 0.86 & 0.32 & 94 & 43 & 3 & 54 \\
\hline & GLdm & AT & $165-175$ & 0.89 & 0.62 & 0.36 & 0.10 & 70 & 19 & 8 & 73 \\
\hline & PZcg & A & $179-182$ & 0.69 & 0.26 & 0.15 & 0.17 & 38 & 27 & 44 & 29 \\
\hline & & $A(E)$ & $183-188$ & 0.37 & 0.28 & 0.10 & 0.20 & 76 & 21 & 9 & 70 \\
\hline & & $\mathrm{Bh}$ & $190-200$ & 0.73 & 0.61 & 0.06 & 0.38 & 84 & 35 & 7 & 58 \\
\hline & & Box & $210-220$ & 0.85 & 0.78 & 0.04 & 0.12 & 92 & 61 & 6 & 33 \\
\hline & & Box & $230-240$ & 0.78 & 0.75 & 0.08 & 0.30 & 96 & 41 & 2 & 57 \\
\hline & & $\underline{G}$ & $250-260$ & 0.38 & 0.23 & 0.09 & 0.17 & 61 & 16 & 10 & 74 \\
\hline & & $\underline{\underline{G}}$ & $300-310$ & 0.24 & 0.15 & 0.01 & 0.13 & 63 & 8 & 5 & 87 \\
\hline \multirow{3}{*}{$\begin{array}{l}\text { Yoldia } \\
\text { (Pai- } \\
\text { kuse) }\end{array}$} & GLem & AT & $310-318$ & 0.24 & 0.23 & 0.27 & 0.09 & 96 & 6 & 0 & 94 \\
\hline & & Bmg & $318-320$ & 0.32 & 0.09 & 0.14 & 0.25 & 44 & 3 & 7 & 90 \\
\hline & & $\underline{G}$ & $320-330$ & 0.16 & 0.14 & 0.03 & 0.18 & 88 & 6 & 1 & 93 \\
\hline $\begin{array}{l}\text { Ancy- } \\
\text { lus } \\
\text { (Pulli) } \\
\end{array}$ & FLem & AG & $200-210$ & 0.65 & 0.44 & 0.20 & 0.13 & 68 & 5 & 3 & 92 \\
\hline \multirow{3}{*}{$\begin{array}{l}\text { Yoldia } \\
\text { (Pulli) }\end{array}$} & GLem & AT & $278-288$ & 0.61 & 0.45 & 0.13 & 0.15 & 74 & 6 & 2 & 92 \\
\hline & & Bmg & $288-295$ & 0.44 & 0.34 & 0.14 & 0.21 & 77 & 5 & 2 & 93 \\
\hline & & & $>295$ & 0.33 & 0.30 & 0.11 & 0.41 & 91 & 5 & 0 & 95 \\
\hline
\end{tabular}

* See Table 1.

Farther from the lakeside (Paikuse) the depth of Ancylus sands above the section of Mollic Gleysol increased. During the low water between the Ancylus regression and the following Litorina transgression about $8000 \mathrm{BP}$ pine stands with birch and some ground vegetation grew on these sands (Thomson, 1928). Trisequal tixotropic fine sand with different relationship of silt, clay, micas, and chemical constituents in layers (Tables 1,3 , and 4) do not have any attributes of pedogenesis at a depth of $240-310 \mathrm{~cm}$. These layers have never reached the surface, neither have they been dry land. Due to the mineral and chemical poverty (Table 3 ) and high water permeability of these sands, the podzolization 
and formation of Carbi-Gleyic Podzol took place within less than 500 years. A high level of the groundwater table and capillary fringe have influenced the vertical range of eluvial pedogenesis. Therefore a dwarf profile (the entire $A-E-B h$ sequence occurs in the limits of $25 \mathrm{~cm}$ ) is characteristic of the Podzol formed. This phenomenon is typical of Gleyic Podzols on any sands of all Baltic transgressions and is connected with the fixation of sesquioxides-organic chelates at the boundary of the capillary fringe (Reintam \& Paas, 1968; Paas, 1985, 1988; Reintam, 1975, 1995). Depending on the different mobility of Aland Fe-organic compounds (Ponomareva, 1964; Mokma \& Buurman, 1982), the humus-illuvial spodic (Bh) horizon consists usually of Al-humic-fulvic complexes, whereas the degree of its compaction is in dependence upon the reductomorphic processes, biological activity, and chemical interactions. Morphologically this Podzol, formed within the warm and humid Litorina Stage, is highly similar to the Podzol described in Greenland and formed under arctic conditions (Humlum et al., 1995). It means that podzolization is characteristic of any Holocene phase in poor and permeable sediments.

As sand particles were slightly weathered, and silt and clay have accumulated in the thin podzolic solum (Table 1), the presumption about the seasonal automorphism seems motivated. The spodic horizon at the boundary of the capillary fringe could even be compacted, more humous and aluminous. An increased humousness of all horizons (Table 2) could be interpreted as a specific of the podzolization in sands (Ponomareva, 1964), but it could entirely be a direct result of an increase in the water table favouring not only the progress of the humus-accumulative process, but also the transformation of humus substances and $\mathrm{R}_{2} \mathrm{O}_{3}$-complexes. An obvious increase in the content of nonsoluble humus poor in nitrogen, and a decrease in the degree of humification in the (former) albic horizon (Table 2) suggest the degradation of podzolization already prior to the temporal overflooding by the Litorina Sea about 7500 BP. According to Pronevich (1928), the decomposition of chelatic complexes, partial solution of their constituents, and degradation ("eating up") of the humus-illuvial horizon will follow from the intensification of ground gleyization. Bilated biogenic uptake into the next, above-lying solum was also possible.

As a result of these phenomena the albic horizon and/or corresponding properties have been destroyed or preserved locally, the spodic horizon has probably become uncemented, impoverished in humus and aluminium, but has conserved its iron-illuvial and iron-humic origin (Table 3). Reciprocal changes in the proportions of aluminium and magnesium could be interpreted by the changes in the crystal lattice of mica minerals (Brindley, 1965), and lateral migration of aluminium pseudosols as well as of ferrous fulvates. Saturation with calcium and its substitution for aluminium in the structure of silicates tends to be influenced later by the increased hydromorphism. Nevertheless, the Podzol section is acid up to present: $\mathrm{pH}$ values in water and salt suspension are 5.1-5.4 and 4.4-4.7, respectively, being higher in the umbric epipedon and lower in the 
spodic horizon. Against the background of podzolization, the amorphous iron has accumulated and preserved in the soil section, the iron activity staying high there (Table 4). Numerous rust-coloured mottlings at a depth of 204-240 cm (Boxhorizon in Fig. 2 and in Tables) demonstrate, against the background of bluish colour, alternate reduction-oxidation processes in root channels of plants with aerenhymic tissues, and winterfrost cracks where seasonal downward removal of solutions enriched with oxygen took place. Reoxidation of ferrous iron, formed already in the sedimentation process of sand, occurred there simultaneously with the development of podzolization above. Obviously, such sporadic reoxidation of the ferrous products of pedogenesis could continue later on, and therefore rusty mottles may have different age in this solum. Conventionally this layer belongs to the subsoil of Carbi-Gleyic Podzol, although textural and chemical differentiations are slight and of sedimentary origin (Tables 1, 3, and 4).

At Pulli the Podzol section above the Fluvisol one was absent or destroyed as a result of contemporary human activity. Earlier, one of us (Tanel Moora) has only described, without sampling, Cambic Arenosol (Cambic Podzol ?) up to $60 \mathrm{~cm}$, and further sand with thin gravel interlayers without properties of pedogenesis up to a depth of $200 \mathrm{~cm}$. Then followed the solum of Eutri-Mollic Fluvisol, which was sampled and is characterized above, with organic matter from the beginning of the Boreal $9300 \pm 75 \mathrm{BP}$ (Ilves et al., 1974).

As a result of the step-by-step transgression and intermittent sedimentation of fine silty sand, at Paikuse in the Early Litorina Stage a short section of Mollic Gleysol was formed during the following 800 years at a depth of $165-179 \mathrm{~cm}$ close to the top of buried Podzol. Without doubt the latter was rooted by the new hydrophilic vegetation, changed under the biological impacts arisen, and at that represented an underground for the Gleysol formation. After unpublished data of Atko Heinsalu and Siim Veski, the pollen of alder and birch, but also graminaceans (Poaceae), sedges (Cyperaceae), meadowsweet and other rosaceans (Rosaceae), umbellifers (Apiaceae), and other hydrophilous herbs of forests and meadows are present there. Within an intensive hydromorphic pedogenesis this thin sediment has almost completely transformed into the mollic epipedon of Gleysol. In spite of acid reaction $\left(\mathrm{pH}_{\mathrm{H}_{2} \mathrm{O}} 5.4, \mathrm{pH}_{\mathrm{KCl}} 4.7\right)$, by other properties it is rarely umbric. It may be the organic layer described already by Thomson (1928) and dated by an embedded wood piece $(6710 \pm 110$ BP ; TA-55) by Kessel \& Punning (1969).

The $\mathrm{R}_{2} \mathrm{O}_{3}$-fulvic-humic epipedon of this Dystri-Mollic Gleysol is poor in humus acids bound with alkaline earths and clay minerals (Table 2), but enriched with some clay, silicate aluminium, potassium, and alkaline earths (Tables 1 and 3). This is the outcome of accumulative hydromorphic pedogenesis, but biogenic and capillary uptake from the deeper and older podzolized solum was also feasible. Very thin (up to $4 \mathrm{~cm}$ ) whitish interlayer between the epipedons of Podzol and younger by 800 years Gleysol represents the unchanged parent material for the latter. This layer is slightly soiled and contains diatoms. The 
presence of both brackish- and freshwater species (by unpublished data of Atko Heinsalu and Siim Veski) allows us to presume the simultaneous increase in the groundwater table which has led to the formation of a freshwater pool and temporal overflooding of the transitional Ancylus-Litorina area with shallow sea water. After the regression of the sea water, Gleysol formation could begin on silty sand which contained diatoms and sedimented in the coastal area of the temporarily transgressive Litorina Sea.

About 7000 BP, the thin section of Mollic Gleysol described was once again covered with aqueous silty sand, in which fine-striped humous interlayers represent a slightly sodded surface characterizing any stratified sandy Fluvisol. We have no data showing whether they are of alluvial origin and formed on the bank of the Pärnu River, or they have formed in the repeatedly flooded coastal area of the transgressive/regressive Litorina Sea. Analogues for these phenomena can be found in modern river vallies and on the seashore, respectively. Anyway, the formation of transgression sediments had ceased here about $6500 \mathrm{BP}$ (Kessel, 1963; Raukas et al., 1995).

Although slight fluvic properties are also present at a depth of $60-85 \mathrm{~cm}$ (Fig. 2), two sections of Arenosols are the uppermost - one (Gleyic) at a depth of about $90-100 \mathrm{~cm}(6500-6700 \mathrm{BP})$ and the other (Cambic) on the very top of the stratum representing the contemporary formation. The deeper of those is essentially more silty and clayey (Table 1 ) and richer in chemical constituents (Table 3), whereas besides sedimentation and pedogenetic accumulation in situ, lateral and downward illuviation of fine particles cannot be excluded. Moreover, Table 2 shows that against the background of some similar humus relationship (total organic carbon and nitrogen, their ratio, degree of humification) buried Gleyic Arenosol is enriched with free fulvic acids (1a fraction), mobile Ca-fulvates (2nd fraction) and mobile $\mathrm{R}_{2} \mathrm{O}_{3}$-humates (1st fraction), but highly poor in humic compounds bound with alkaline earths and clay minerals (2nd and 3rd fractions) and humus fixed in the structure of minerals. Such a situation could rarely arise because of the conservation of active pedogenesis under the cover of extremely poor (aeolian?) sand (Tables 1,3 , and 4), but is due to the infiltration of active fulvates which are in charge of continuous interactions outside their origination, as well as are able to mobilize more abundant mineral potential. A recrystallization of the amorphous products of weathering tends to be inhibited under seasonal reductomorphic conditions there. Cambic Arenosol on the very top of the outcrop shows a weak textural and chemical differentiation, and only light brownish colour reflects the sluggish mobilization of iron within and below the ochric epipedon formed apparently during more than six millennia. Such a slow rate of Holocene pedogenesis is characteristic of any kind of the sands (Syers et al., 1970; Mahaney et al., 1980; Reintam, 1996). 


\section{CONCLUSIONS}

The presence of herbaceous vegetation, verified by the bones of herbivores and relatively thermophilic fishes amongst the archaeological findings, demonstrates the devolopment of the humus-accumulative process already within the Yoldia Stage. Initial pedogenesis had to be automorphic, because the cambic properties appeared could not have developed under the aquic regime characteristic of the Pre-Boreal. The evolution of Arenosols and/or Cambisols into Mollic Gleysols was rapid and lasted about 700-1200 years with the mean annual rate of $1.1-2.3 \mathrm{~g} \mathrm{~m}^{-2}$ organic carbon per $1 \mathrm{~cm}$ of the mollic epipedon enriched with phosphorus, iron, and alkaline earths in the area of the Pulli settlement. Their epipedon coincides with the cultural layer there. Mineral constituents make $>70 \%$ of the mollic epipedon with perfect fulvic-humic humus, rich in insoluble fractions, but with a low degree of humification. Argillization and related changes in the chemical characteristics had taken place prior to the progress of Gleysols, but changes in mineralogical and chemical relationships during montmorillonitization and vermiculitization are due to the reductomorphic phenomena within the genesis of Gleysol sections. These sections have completely preserved below the younger sequences of soils.

Sandy and silty sediments of the Ancylus transgression buried the Gleysols formed. Close to the coastal part of the Ancylus Lake, Fluvisol formation began directly above the buried solum. As the properties of Eutri-Mollic Fluvisol, formed during some millennia, are highly similar to those of Gleysols developed within a manyfold shorter space of time, a significant decrease in the intensity of pedogenesis happened under the alluvial regime. After the regression of the Ancylus Lake about 8000 BP, within the Early Litorina Stage (during about 500 years) the podzolization of the upper $25 \mathrm{~cm}$ of sands developed. The main stratum of the sands never reached the surface, and was never changed by pedogenetic processes, but was subjected only to seasonal and sporadic reoxidation of ferrous compounds of sedimentary origin. Both albic and spodic horizons of Carbi-Gleyic Podzol have degraded already prior to the temporal overflooding by the Litorina Sea about $7500 \mathrm{BP}$ as a result of an increase in ground gleyization. Degradation processes continued after the temporal transgression of the Litorina Sea when Podzol was overflooded, buried by thin fine silty sand, and became underground for the following hydromorphic pedogenesis on the material enriched with diatoms and populated by the hydrophilous herb vegetation.

The main properties of Mollic Gleysol, formed within the Early Litorina Stage during about 800 years on the sand underlain by the section of Podzol, are closely similar to those of the Gleysols of the Yoldia Stage. Even the rate of humus accumulation was the same, demonstrating the principal unitarity of hydromorphic pedogenesis within any Holocene phase. Simultaneously with the 
direct outcome of accumulative soil processes in situ, biogenic and capillary uptake from the deeper sola is feasible under aquic conditions.

Stratified, either alluvial or transgressive/regressive Litorina sandy-silty Fluvisols cover the section of Mollic Gleysol. Two sections of Arenosols are the uppermost ones, whereas the Cambic section on the very top of fine sand is weakly differentiated. Only light brownish colour reflects the sluggish formation of nonsiliceous coatings on quartz grains. The ochric epipedon has formed during more than six millennia and demonstrates the extremely slow rate of pedogenesis on arid sand.

Pedogenetic interpretation constitutes a perspective basis for characterizing the history of any territory and discussing about the paleogeography.

\section{ACKNOWLEDGEMENTS}

This study was supported by the Estonian Science Foundation grant No. 2669 . We would like to thank Raja Kährik, a research assistant, who carried out all the laboratory analyses. Special thanks are due to Prof. Dr. Anto Raukas for his kind help, valuable suggestions, and fruitful co-operation in connection with the current and other studies. Thanks are also extended to Atko Heinsalu and Siim Veski for the permission to use some unpublished data.

\section{REFERENCES}

Aleksandrovski, A. L. 1983. Évolyutsiya pochv Vostochno-Evropeiskoj ravniny v golotsene. Nauka, Moscow (in Russian).

Arinushkina, E. V. 1970. Rukovodstvo dlya khimicheskogo analiza pochv. Moscow University Press (in Russian).

Barshad, I. 1948. Vermiculite and its relation to biotite as revealed by base exchange reactions, $\mathrm{X}$-ray analysis, differential thermal curves and water content. Am. Mineralogist, 33, 655-678.

Brindley, C. W. 1965. Chlorite Minerals. The X-Ray Identification and Crystal Structures of Clay Minerals. Moscow (Russian translation).

Buol, S. W., Hole, F. D. \& McCracken, R. J. 1989. Soil Genesis and Classification. Third Edition. The Iowa State University Press, Ames.

FAO - UNESCO. 1994. Soil Map of the World. Revised Legend with Corrections. ISRIC, Wageningen.

Gorbunov, N. I. 1978. Mineralogiya i fizicheskaya khimiya pochv. Nauka, Moscow (in Russian).

Huckriede, H., Clasen, S. \& Meischner, D. 1996. Hydrographic and climatic changes recorded in Holocene sediments of the Central Baltic Sea. Baltica, 9, 76-91.

Humlum, Christiansen, Hansen, Hasholt, Jakobsen, Nielsen \& Rash. 1995. Holocene landscape evolution in the Mellemfjord area, Disko island, Central West Greenland: Area presentation and preliminary results. Danish J. Geogr., 95, 28-41.

Ilves, E., Liiva, A. \& Punning, J.-M. 1974. Radiocarbon Dating in the Quaternary Geology and Archaeology of Estonia. Eesti NSV Teaduste Akadeemia, Tallinn. 
Indreko, R. 1948. Die mittlere Steinzeit in Estland mit einer Übersicht "Über die Geologie des Kunda-Sees" von K. Orviku. Kunglinga Vitterbets Historic och Aktivitets Akademiens Bandlingar, 66. Stockholm.

Jaanits, L., Laul, S., Lõugas, V. \& Tõnisson, E. 1982. Eesti esiajalugu. Eesti Raamat, Tallinn.

Jakobsen, B. H. 1991. Multiple processes in the formation of subarctic Podzols in Greenland. Soil Science, 152, 6, $414-426$.

Jakobsen, B. H. 1992. Aspects of the genesis, geography and evolution of the soils in Greenland. Proc. of the 1st Internat. Conference on Cryopedology. Pushcino. SNG., 71-84.

Keeley, H. C. M. 1990. Anthropogenic influences on pedogenesis in the British Isles, with particular examples from the Later Prehistoric Period. Trans. of 14th Congr. of Soil Sci. V. V, Comm. V. Kyoto-Japan, 363-364.

Kessel, H. 1963. Holocene coastal formations on the coast of Southwest Estonia. Eesti NSV Tead. Akad. Geol. Inst. Uurimused, XII, 123-144 (in Russian).

Kessel, H. \& Punning, J.-M. 1969. Über die Verbreitung und Stratigraphie der Sedimente des Joldiameeres in Estland. Eesti NSV TA Toim. Keemia. Geol., 18, 2, 154-163.

Klein, C. \& Hurlbut, C. S., Jr. after James D. Dana. 1993. Manual of Mineralogy. John Wiley \& Sons, INC. New York.

Lillema, A. 1958. Eesti NSV mullastik. Eesti Riiklik Kirjastus, Tallinn.

Mahaney, W. C., Rees, H. W., Rutter, N. W., Smith, S. \& Tedrow, J. C. F. 1980. Holocene Soils in Canada: A Review. Ontario, Canada.

Mokma, D. L. \& Buurman, P. 1982. Podzols and Podzolization in Temperate Regions. ISM Monograph 1. Int. Soil Museum, Wageningen.

Morozova, T. D. 1981. Razvitie pochvennogo pokrova Evropy v pozdnem pleistotsene. Nauka, Moscow (in Russian).

Orlov, D. S. 1985. Humus Acids of Soils. A. A. Balkeme, Rotterdam.

Paas, A. 1964. Über die Rasengleiböden der Pärnu-Niederung. Yearbook of the Estonian Naturalists' Society. Tartu, 56, 25-56.

Paas, A. Yu. 1979. Properties and dynamics of physico-chemical indices of gley soils derived from graded clay and two-storied deposits. Pochvovedenie (Soviet Soil Science), 12, 32-40 (in Russian).

Paas, A. Yu. 1985. Regularities in the pattern of soils on the deposits of the Baltic Sea transgressions. Pochvovedenie (Soviet Soil Science), 12, 5-13.

Paas, A. Yu. 1988. Podzolic-gley soils on sandy Baltic sediments. Pochvovedenie (Soviet Soil Science), 12, 49-58.

Ponomareva, V. V. 1957. To the method for the study of soil humus after I. V. Tyurin's scheme. Pochvovedenie (Soviet Soil Science), 8, 66-71.

Ponomareva, V. V. 1964. Theory of Podzolization. Nauka, Moscow-Leningrad (in Russian); Israel Program for Scientific Translations. Jerusalem, 1969 (in English).

Pronevich, A. 1928. Kharakter vyshchelochennogo gorizonta lesnoj podzolistoj pochvy i ego otnoshenie k morfologicheskomu podzolistomu gorizontu.) In Pamyati K. D. Glinki. Leningrad (in Russian).

Raukas, A. \& Hyvärinen, H. (eds.). 1992. Geology of the Gulf of Finland. Estonian Acad. Sci., Acad. Finland, Tallinn.

Raukas, A., Saarse, L. \& Veski, S. 1995. A new version of the Holocene stratigraphy in Estonia. Proc. Estonian Acad. Sci. Geol., 44, 4, 201-210.

Reintam, L. 1975. A new approximation to the soil typology in the Estonian S.S.R. In Some Aspects of Botanical Research in the Estonian S.S.R. (Laasimer, L., ed.). Tartu, 109-122.

Reintam, L. 1995. Muldade kujunemine. In Eesti. Loodus (Raukas, A., ed.). Eesti Entsüklopeediakirjastus, Valgus, Tallinn, 419-430; 566-567; 593-595.

Reintam, L. 1996. On genesis and taxonomy of brown-colored sandy forest soils. Eurasian Soil Science, 29, 4, 395-401. 
Reintam, L. 1997. Soil formation. In Geology and Mineral Resources of Estonia (Raukas, A. \& Teedumäe, A., eds.). Tallinn, 298-306.

Reintam, L. \& Paas, A. 1968. Kompleks pochv podzolisto-gleevogo i dernovo-gleevogo tipov na peskakh Limnievogo perioda. In Khimiya, genezis $i$ kartografiya pochv (Glazovskaya, M. A. \& Kaurichev, I. S., eds.). Nauka, Moscow, 153-160 (in Russian).

Rooma, I. 1996. Muldkate, 1 : 1500 000. In Eesti atlas koolidele (Aunap, R., ed.). Avita, Tallinn, $16-17$.

Rooma, I. \& Reintam, L. 1976. Soil map of the Estonian S.S.R. In Trans. of the Tartu State University, 393. Publications on Geography XII. On the occasion of the XXIII Internat. Geographical Congress, 77-82.

Soil Survey Laboratory Methods Manual, 1996. Soil Survey Investigations Report No 42, Version 3.0.

Syers, J. K., Adams, J. A. \& Walker, T. W. 1970. Accumulation of organic matter in a chronosequence of soils developed on wind-blown sand in New Zealand. J. Soil Sci., 21, 146-153.

Thomson, P. W. 1928. Das geologische Alter der Kunda- und Pernaufunde (vorläufige Mitteilung). Beiträge zur Kunde Estlands, XIV, 1, 1-9.

Thomson, P. W. 1930. Die regionale Entwicklungsgeschichte der Wälder Estlands. Acta et Comment. Univ. Tartuensis, XVII, 2, 88.

Zonn, S. V. 1982. Iron in Soils (Genetic and Geographical Aspects). Nauka, Moscow (in Russian). Zonn, S. V. 1986. Tropical and Subtropical Soil Science. Mir Publishers, Moscow.

\section{MULLATEKKEPROTSESSI ARENG LÄÄNE-EESTI VEESETETEL HOLOTSEENIS}

\section{Loit REINTAM ja Tanel MOORA}

Pulli muinasasulas ja Paikusel uuriti holotseeni erinevatel ajajärkudel kujunenud ja seetõttu üksteisel lasuvate muldade paljandeid. Mullatekkeprotsess algas siin viirsavi õhukese kihina katval veesettelisel tolmjal liival ja liivakal liivsavil umbes 10400 aastat tagasi pärast Balti jääpaisjärve kiiret taandumist. 9600 aastat tagasi eksisteerinud Pulli asula leidude seas identifitseeritud rohusööjate luud näitavad rohtse taimkatte ning sellest johtuva huumus-akumulatiivse mullatekkeprotsessi olemasolu juba Joldiamere ajajärgul. Savistunud horisondiga küllastunud gleimuld (Eutri-Mollic Gleysol) on 700-1200 aasta jooksul arenenud mullatekke tulemus. Tema evolutsioon pidi ilmselt algama nõrgalt diferentseerunud savi-akumulatiivse horisondiga küllastunud liivmuldadest (Cambic Arenosol), sest savistumine automorfse protsessina ei saa analüüsidest selgunud ulatuses toimuda lahustumata huumusainete kogunemist soodustavas, kestvalt veega küllastatud keskkonnas. Orgaanilise süsiniku aastane juurdekasv $(1,1-$ 2,3 $\mathrm{g} \mathrm{m}^{-2}$ huumushorisondi $1 \mathrm{~cm}$ kohta) on olnud suur, moodustunud humaatne huumus täiuslik ning vaid kuni kolmandiku ulatuses leelistes lahustuv. Muinasasula piires on huumushorisont märgatavalt rikastunud fosfori, raua ja leelismuldmetallidega. Küllastunud (turvastunud) gleimulla keemiline koostis ise- 
loomustab protsesse, mis arenevad mullatüsendi mineraalosas veega küllastatud ja hapnikuvaegses keskkonnas.

9000-9500 aastat tagasi mattusid Joldiamere ajal tekkinud gleimullad (ka muinasasula) Antsülusjärve tolmjate ja liivaste setete alla, säilitades tänaseni oma ehituse ja omadused. Pulli ümbrus on ilmselt olnud Antsülusjärve kaldaala ning seal katab gleimuldi kihiliste lammi-gleimuldade tüsend, mis näitab Antsülusjärve vahelduvat taandumist ja taas pealetungi. Järve kaldast kaugemal (Paikusel) on peenliiv tüsedam, paksude kihtidena sorteeritud ning nende allosas mullatekkest kas üldse mõjutamata või on seal toimunud vaid settimisel moodustunud alahapendiliste ühendite osaline tagasihapendumine juurekäikudes ja talvistes külmalõhedes liikunud hapniku osalusel. Antsülusjärve regressioonil on Litoriinamere varasel ajajärgul ülemises $25 \mathrm{~cm}$ tüseduses liivakihis umbes 500 aasta jooksul (7500-8000 aastat tagasi) arenenud leetumine. Moodustunud kääbusprofiiliga huumus-illuviaalne leet-gleimuld (Carbi-Gleyic Podzol) on oma ehituse ja näitajatega sarnane tänaseni Antsülusjärve, Litoriinamere ja Limneamere transgressioonialadel levivate leet-gleimuldadega. Põhjaveetaseme tõus ja sellele järgnenud Litoriinamere ajutine pealetung ei toonud endaga kaasa mitte üksnes huumus-illuviaalse leetprofiili osalist degradatsiooni, vaid kattis selle täielikult õhukese ränivetikaid sisaldanud liivakihiga. Umbes 800 aasta jooksul (6700-7500 aastat tagasi) arenes sellel Joldiamere-aegsele gleimullale väga sarnaste omadustega, kuid küllastumata gleimuld (Dystri-Mollic Gleysol). Mullatekkest jäi siin mõjustamata vaid imeõhuke tänaseni ränivetikaid sisaldav kiht. Ilmselt paarisaja aasta jooksul moodustunud kihiline lammi-gleimuld või koguni ranniku-gleimuld katab sedagi gleimulda. Paljandi ülemisteks liikmeteks on kaks nõrgalt diferentseerunud profiiliga liivmulda (Arenosol), millest ülemine (Cambic Arenosol) on küll enam kui 6000 aastat olnud mullatekkeprotsessidest haaratud, kuid on ikkagi vähehuumuslik ning helepruuni amorfse raudoksiidi kelmega kvartsiteradel.

\title{
РАЗВИТИЕ ПОЧВООБРАЗОВАНИЯ НА ВОДНЫХ ОТЛОЖЕНИЯХ ЗАПАДНОЙ ЭСТОНИИ В ГОЛОЦЕНЕ
}

\author{
Лойт РЕЙНТАМ и Танел МООРА
}

Исследованы обнажения с разновозрастными почвами на отложениях балтийских трансгрессий в окрестностях Пайкузе и древнего поселения Пулли. Почвообразование началось здесь после отступания Балтийского ледникового озера, примерно 10400 лет назад, на пылевато-песчаных отложениях, подстилаемых ленточными глинами. В связи с возросшим гидроморфизмом первичные слабооглиненные песчаные почвы быстро превратились в насыщенные перегнойно-глеевые. Примерно 9600-9000 лет 
назад эти полноразвитые почвы покрылись песками Анцилового озера, на которых в окрестностях Пулли развились слоистые пойменные почвы и в окрестностях Пайкузе - карликовые гумусо-иллювиальные подзолистые почвы. Последние подверглись деградации в связи с поднятием уровня грунтовых вод почти до земной поверхности, причем еще до временного наступления Литоринового моря. На тонком слое песка, подстилаемом гумусо-иллювиальным подзолистым профилем, в течение последующих 800 лет (6700-7500 лет назад) развивалась ненасыщенная перегнойно-глеевая почва. Самыми последними являются два профиля недифференцированных песчаных почв, под которыми (над глеевой почвой) залегает толща слоистых либо пойменных, либо прибрежных почв. 